УДК $005.932: 338.242$

DOI: $10.15673 /$ fie.v12i2.1734

\author{
Нікішина О.В. \\ доктор економічних наук, старший науковий співробітник \\ завідувач відділу ринкових механізмів та структур \\ Інститут проблем ринку та економіко-екологічних досліджень НАН України \\ Французький бульвар, 29, м. Одеса, Україна, 65044 \\ E-mail: ksenkych@gmail.com \\ ORCID ID: 0000-0002-7172-3551
}

\title{
ТЕОРЕТИКО-МЕТОДОЛОГІЧНЕ ЗАБЕЗПЕЧЕННЯ ДІАГНОСТИКИ ЕФЕКТИВНОСТІ ЛОГІСТИЧНИХ ЛАНЦЮГІВ ТОВАРНИХ РИНКІВ *
}

Стаття присвячена обґрунтуванню теоретичних і методологічних засад системної діагностики ефективності функціонування логістичних ланцюгів товарних ринків. На підставі теоретичного узагальнення виділено три підходи до визначення сутності категорії «ефеективність логістичної системи». Доведено доцільність використання комплексного підходу для діагностики ефективності ринкових ланцюгів, який забезпечує збалансованість якісних і кількісних показників, поєднання внутрішнього й зовнішнього вимірів ефективності. За результатами аналізу категорій «ефективність» і «діагностика» у ринковологістичному вимірі надано авторське визначення категорії «діагностика ефективності логістичних ланцюгів товарних ринків». Обґрунтовано складові концептуального базису на основі синтезу чотирьох підходів (відтворювального, регуляторного, концепцій діаграми збалансованих переваг та сталого розвитку), доведено їх взаємопов'язаність між собою спільною відтворювальною основою та їх кореляцію із відповідними групами принципів формування ефективних ланцюгів товарних ринків. Обґрунтовано компоненти теоретико-методологічного забезпечення діагностики ефективності логістичних ланцюгів товарних ринків у двоєдності концептуального та методичного базисів, як наукове підґрунтя для розробки механізмів і заходів державного регулювання базових ланок ланцюгів стратегічних товарних ринків.

Ключові слова: ефективність, діагностика, підхід, логістичний ланцюг товарного ринку, принципи діагностики, додана вартість, система показників.

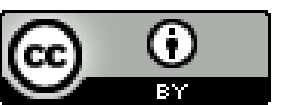

This work is licensed under a Creative Commons Attribution 4.0 International License http://creativecommons.org/licenses/by/4.0/
Постановка проблеми та її зв'язок з важливими науковими та практичними завданнями. В умовах глобальної нестабільності важливою умовою відтворювального розвитку національної економіки $\epsilon$ ефективне функціонування логістичних ланцюгів товарних ринків (далі - ЛЛТР), у ланках яких відбувається процес продукування й розподілу доданої вартості, що є внутрішнім ресурсом розвитку країни. Обгрунтування шляхів, механізмів та інструментів підвищення ефективності ЛЛТР обумовлює необхідність розробки нового теоретико-методологічного забезпечення діагностики ефективності функціонування або трансформації даних ланцюгів з урахуванням вимог турбулентного зовнішнього середовища та постановки багатовимірних завдань.

Сьогодні теорія ефективності як наука активно розвивається, що сприяло зростанню кількості визначень та поглиблення значень терміну в кількісно-якісному аспектах. Питання ідентифікації категорії «ефективність» у сфері логістики однозначно не вирішено, обумовлюючи необхідність нових досліджень для конструювання системи показників діагно- стики логістичної діяльності (далі - ЛД) підприємств (мікрорівень) та потокових процесів товарного ринку (макрорівень). Слід зазначити, що існуючі теоретикометодичні напрацювання у сфері ефективності логістики стосуються, передусім, мікрологістичних систем. Невирішене завдання діагностики ефективності функціонування макрологістичних ринкових систем генерує широке наукове поле для подальших інноваційних досліджень. Актуальність обраної теми обумовлена необхідністю розвитку теоретикометодологічних засад діагностики ефективності ЛЛТР з акцентом на відтворювальний підхід, тому що це підгрунтя $\epsilon$ науковою основою для розробки механізмів і заходів регуляторного впливу держави на базові ланки ланцюгів стратегічних ринків.

Аналіз останніх публікацій по проблемі. Проблема концептуально-методичного забезпечення оцінки ефективності логістичних систем багатопланова й багатоаспектна, iї зміст грунтовно досліджу ється вітчизняними й іноземними науковцями, що свідчить про значний дослідницький інтерес.

Достовірність такого твердження підтвер-

* Публікацію підготовлено в межах виконання НДР «Формування ефективної логістики товарних ринків» (№ державної реєстрації 0119U000227). 
джена науковими напрацюваннями Вітковські Я. [1], Гудкова В.А. [2], Гурч Л.М. [3], Кристофера М. [4], Міротіна Л.Б [5], Осипенко С.М. [6], Пономарьової Ю.В. [7], Руденко Г.Р [8], Сагайдак-Нікітюка Р.В. [9], Семененко А.I. [10], Сумця О.М. [11], Талан М.В [12] та інших учених. Питання діагностики мікро- й мезоекономічних систем досліджували Дмітрієва О.Г. [13], Ковальов А.І. [14], Новосьолов О.С. [15], Шніпер P.I. та ін. Основна увага науковцями приділяється теоретико-методичним основам оцінки ефективності логістичної діяльності підприємств. Водночас недостатньо вивченими залишаються питання обгрунтування концептуальної сутності категорій «ефективність» і «діагностика» у ринково-логістичному виміpi, а також методологічних підходів до діагностики ефективності макрологістичних систем, зокрема ринкових.

Формулювання цілей дослідження. Мета статті - розробка теоретико-методологічних засад системної діагностики ефективності функціонування ЛЛТР, як підгрунтя для управлінського впливу - визначила низку завдань:

1) обгрунтувати багатовимірну сутність дефініції «ефективність» у логістичній площині, надати авторське визначення категорії «діагностика ефективності логістичних ланцюгів товарних ринків»;

2) визначити компоненти концептуального базису, їх взаємопов'язаність між собою та з групами принципів формування ефективних ринкових ланцюгів;

3) обгрунтувати структуру теоретикометодологічного забезпечення, завдання, принципи й методичні положення діагностики ефективності ЛЛТР, визначити їх логічний зв'язок із механізмами державного регулювання.

Виклад основних результатів та їх обгрунтування. Теоретичною основою побудови системи взаємодоповнюючих показників для комплексної оцінки та системної діагностики ефективності функціонування ЛЛТР є визначення економічної природи дефініцій «ефективність» та «діагностика» у ринковологістичному вимірі.

На думку О. I. Момот, загальна дефініція «ефективність» (у перекладі з лат. - дієвий, продуктивний, що дає результат) характеризує різні розвинені системи, процеси, явища. Ефективність виступає як індикатор розвитку та $\epsilon$ його найважливішим стимулом. Як категорія вона має дві сторони - якісну та кількісну [16, с. 208]. Водночас, на думку С. В. Мочерного, як економічна категорія ефективність дає єдину якісно-кількісну характеристику результативності господарювання [17, с. 508].

Економічну сутність дефініції «ефективність» по відношенню до логістичної системи (мікрорівень) або ЛД підприємств учені інтерпретують порізному. Це обумовлено складністю та багатоаспектністю вихідної категорії, а також істотними розбіжностями щодо іiі природи та методів оцінки. Найпоширеніші трактування дефініції узагальнено в таблиці 1. У ході проведеного дослідження нами виділено три головні підходи, які дозволяють об'єднати суку- ність неоднорідних трактувань у групи, а саме:

(1) якісний - цільовий і споживчоорієнтова-

ний;

(2) кількісний - ресурсний і результуючий;

(3) комплексний - синтезуючий якісний і кількісний підходи.

У межах якісного підходу можна виділити два напрями: (1) цільовий, орієнтований на оцінку ступеня фактичного досягнення результату, тобто мети i завдань логістичної системи; (2) споживчоорієнтований, що відображає позитивний ефект у задоволенні потреб споживачів і оцінює якість їх обслуговування (табл. 1). Так, деякі науковці $[2,5]$ оцінювати ефективність ЛД систем пропонують через визначення рівня задоволення вимог споживачів щодо доставки замовлених товарів або надання логістичних послуг. Водночас такий підхід $є$ неповним і не відображає стан досягнутих економічних результатів, який може бути низьким за високого рівня логістичного обслуговування споживачів.

Кількісний підхід до визначення ефективності логістичних систем акцентує увагу на множині показників іï кількісної оцінки, які можна розділити на показники ресурсної та результуючої ефективності (див. табл. 1). Прихильники ресурсного підходу акцентують увагу на економічних ефектах у площині оптимального використання ресурсів (матеріальних, інформаційних, фінансових, трудових), переміщенні товарів за ланками логістичного ланцюга за найменших витрат ресурсів. Відповідно до положень стандарту ISO 9000:2007 [18], ефективність (англ. efficiency) - це співвідношення між досягнутим результатом і використаними ресурсами. Представники результуючого підходу $[6,8]$ визначають ефективність логістичної системи як співвідношення між результатом ЛД і витратами на його отримання.

Множина показників, сформована у межах кількісного підходу, складається, як правило, із непрямих показників логістичної діяльності, що відображають фінансово-економічний стан ринкових суб'єктів. Відтак, головним недоліком даного підходу $\epsilon$ недостатній причинно-наслідковий зв'язок загальних показників економічної ефективності і стану логістичної системи та її складових ланок, неможливість конкретизації логістичних проблем, шляхів та інструментарію їх вирішення 3 урахуванням впливу зовнішнього середовища.

Комплексний підхід до трактування категорії «ефективність логістичної системи», як синтез якісного й кількісного підходів, впроваджено в логістиці мікросистем (див. табл. 1). У межах даного підходу науковці визначають вихідну категорію як систему показників, що характеризує рівень якості функціонування логістичної системи за заданого рівня загальних логістичних витрат $[3,5]$. Тобто йдеться про синтез певних якісних і кількісних показників оцінки ефективності логістичної системи, перелік яких $\epsilon$ варіативним і динамічним, залежить від сфери діяльності суб'єктів господарювання, мети й користувачів результатів такої оцінки, наявної інформаційної бази тощо. 
Сутність економічної категорії «ефективність логістичної системи» у трактуванні різних авторів"

Таблиця 1

\begin{tabular}{|c|c|c|}
\hline ПІДХІД & Автори & Визначення категорій \\
\hline \multirow{3}{*}{$\begin{array}{l}\text { І. Якісний: } \\
\text { 1.1. Цільовий: } \\
\text { ступінь фактич- } \\
\text { ного досягнення } \\
\text { результату }\end{array}$} & $\begin{array}{l}\text { Міротін Л.Б., } \\
\text { Ташбаєв I.Е. [5, с. 472] }\end{array}$ & $\begin{array}{l}\text { Ефективність ЛД - ступінь фактичного досягнення резуль- } \\
\text { тату; співвідношення між фактично отриманим результатом } \\
\text { функціонування системи і цільовим показником. }\end{array}$ \\
\hline & $\begin{array}{l}\text { Семененко O.I, } \\
\text { Сергєєв B.I. [10] }\end{array}$ & $\begin{array}{l}\text { Ефективність ЛД - відповідність діяльності підприємства } \\
\text { встановленим цілям }\end{array}$ \\
\hline & $\begin{array}{l}\text { Сагайдак-Нікітюк Р.В. } \\
{[9, \text { с.32-33] }}\end{array}$ & $\begin{array}{l}\text { Ефективність ЛД - ступінь досягнення логістичних зага- } \\
\text { льних і локальних завдань, що стоять перед підприємством, } \\
\text { за умови оптимального використання всіх його ресурсів } \\
\text { (матеріальних, інформаційних і фінансових). }\end{array}$ \\
\hline \multirow{2}{*}{$\begin{array}{l}\text { 1.2.Споживчо- } \\
\text { орієнтований: } \\
\text { якість обслуго- } \\
\text { вування спожи- } \\
\text { вачів, позитив- } \\
\text { ний ефект у за- } \\
\text { доволенні пот- } \\
\text { реб споживачів }\end{array}$} & $\begin{array}{l}\text { Пономарьова Ю.В. } \\
\text { [7, с. 206]; } \\
\text { Міротін Л.Б., } \\
\text { Ташбаєв I.Е. [5, с. 472] }\end{array}$ & $\begin{array}{l}3 \text { точки зору споживача, ефективність логістичної системи } \\
\text { визначається рівнем якості обслуговування його замовлен- } \\
\text { ня }\end{array}$ \\
\hline & $\begin{array}{l}\text { Гудков В.А., Міротін Л.Б., } \\
\text { Ширяєв С.А., Гудков Д.В. } \\
\text { [2] }\end{array}$ & $\begin{array}{l}\text { Ефективність ЛД - ступінь задоволення потреб споживача. } \\
\text { Оцінка рівня задоволення вимог клієнтів щодо доставки } \\
\text { замовлених товарів або надання логістичних послуг. }\end{array}$ \\
\hline \multirow{4}{*}{$\begin{array}{l}\text { IІ. Кількісний } \\
\text { 2.1. Ресурсний: } \\
\text { оптимальне } \\
\text { використання } \\
\text { ресурсів } \\
\text { 2.2. Результу- } \\
\text { ючий: } \\
\text { співвідношення } \\
\text { результату з ви- } \\
\text { тратами }\end{array}$} & $\begin{array}{l}\text { Устенко О.Л., } \\
\text { Шеремет А.Д., } \\
\text { Сайфулін Р.С. [16] }\end{array}$ & $\begin{array}{l}\text { Ефективність відображає результат (ефект) з точки зору } \\
\text { оптимального використання ресурсів (матеріальних, інфор- } \\
\text { маційних, фінансових, трудових) }\end{array}$ \\
\hline & $\begin{array}{l}\text { Стандарт ISO 9000:2007 } \\
{[18]}\end{array}$ & $\begin{array}{l}\text { Ефективність - співвідношення між досягнутим результа- } \\
\text { том і використаними ресурсами }\end{array}$ \\
\hline & Осипенко С.М. [6] & $\begin{array}{l}\text { Ефективність ЛС-це співвідношення між результатом } \\
\text { логістичної діяльності і витратами на його отримання (тоб- } \\
\text { то величина відносна) }\end{array}$ \\
\hline & Руденко Г.Р. [8] & $\begin{array}{l}\text { Ефективність ЛД (машинобудівного підприємства)- це } \\
\text { відношення додаткового доходу від здійснення ЛД до логі- } \\
\text { стичних витрат у сферах постачання, виробництва, збуту, } \\
\text { складування, транспортування та сервісу. }\end{array}$ \\
\hline \multirow{2}{*}{$\begin{array}{l}\text { ІІІКомплексни } \\
\text { й } \\
\text { (синтез якісного } \\
\text { й кількісного } \\
\text { підходів) }\end{array}$} & $\begin{array}{l}\text { Пономарьова Ю.В. } \\
\text { [7, с. 205]; } \\
\text { Гурч Л.М. [3, с. 239] }\end{array}$ & $\begin{array}{l}\text { Ефективність логістичної системи - показник (або систе- } \\
\text { ма показників), який характеризує рівень якості функціо- } \\
\text { нування логістичної системи за заданого рівня загальних } \\
\text { логістичних витрат. }\end{array}$ \\
\hline & Witkowski J. [1] & $\begin{array}{l}\text { Критерії моделювання логістичних стратегій: зменшення } \\
\text { сукупних витрат; диференціація логістичного обслугову- } \\
\text { вання клієнтів; інноваційність. }\end{array}$ \\
\hline
\end{tabular}

*Узагальнено автором із використанням джерел [1- 10, 16-18]

Досягнення консенсусу між рівнем логістичного обслуговування відповідно до вимог споживачів i величиною логістичних витрат є головною метою логістичної стратегії. Іноземні учені, зокрема Я. Вітковскі, у процесі моделювання логістичних стратегій виділяє такі якісно-кількісні критерії: (1) зменшення сукупних витрат; (2) диференціація логістичного обслуговування клієнтів; (3) інноваційність. При цьому критеріями інноваційності є мінімум сукупних логістичних витрат, максимум доданої вартості за існуючих витрат та еластичність логістичної системи, тобто швидке пристосування до змін в оточенні [1]. Вказаний підхід до моделювання логістичних стратегій доцільно віднести до комплексного з огляду на синтез якісних і кількісних критеріїв (див. табл. 1). Також даний підхід є дотичним до цільового орієнтиру логістики товарного ринку - розширене відтворення товароруху та оптимізація загальної ринкової доданої вартості [19].

Врахувавши характеристики різних підходів до визначення сутності категорії «ефективність логістичної системи» (див. табл. 1), у даному дослідженні буде використано комплексний підхід до теоретичного осмислення та діагностики потокових процесів у межах товарних ринків, який, на наш погляд, $є$ найбільш повним, всебічним, містить компоненти відтворювального підходу та орієнтований на динамічну комплексну оцінку множини індикаторів. Графічно комплексний підхід до діагностики ефективності ЛЛТР, як синтез якісних і кількісних показників, збалансованість (консенсус) яких забезпечує конкурентоспроможність ринкових ланцюгів, представлено на рис. 1.

Наведені на рис. 1 компоненти комплексного підходу тісно пов'язані із концепцією результативності та ефективності, поширеною серед іноземних учених, які досліджують нові підходи до маркетингу, закупівель, технологічного розвитку та інтерактивного управління в В2В- і В2C-контексті - IMP Group (Industrial Marketing and Purchasing Group). Вони вва 
жають, що ефективність - це внутрішній стандарт продуктивності, який визначає використання ресурсів підприємством, а результативність - зовнішній стандарт продуктивності, що визначає ступінь задоволення потреб різних груп споживачів [18]. Аналіз зовні- шнього середовища логістичної системи М.Талан називає аналізом «логістичного оточення», який враховує зовнішні чинники впливу на ефективність функціонування даної системи [12, с.698].

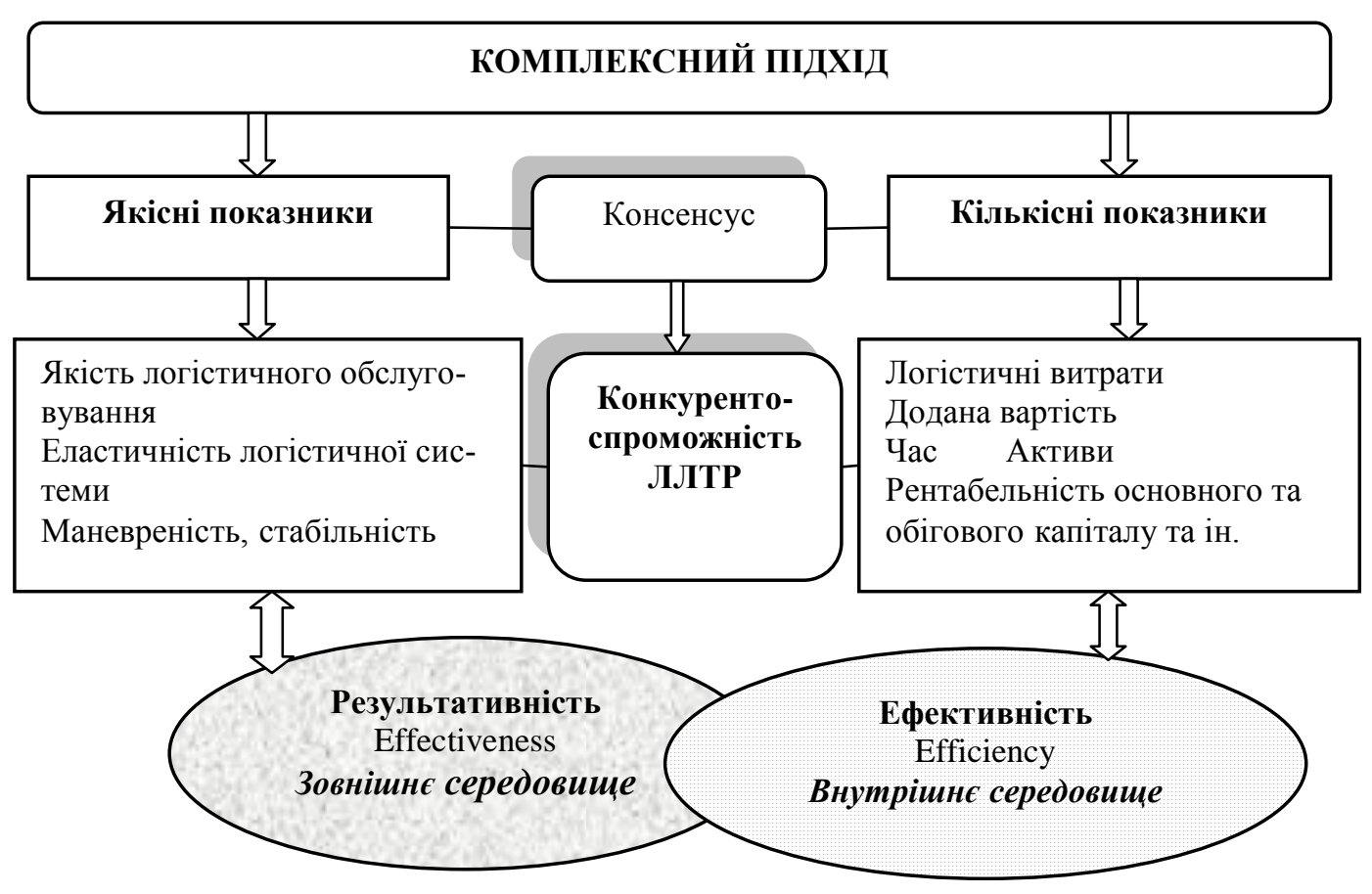

Рис. 1. Синергія посднання компонентів комплексного підходу до діагностики ефективності логістичної системи * розроблено автором з використанням джерел $[1,3,18]$

Згідно зі стандартом ISO 9000:2007, резульmaтивність (англ. effectiveness) - це ступінь реалізації запланованих дій та досягнення запланованих результатів, а ефективність (англ. еfficiency) - це співвідношення між досягнутим результатом і використаними ресурсами [18]. Тобто перше визначення доцільно віднести до якісного цільового підходу, а друге - до кількісного ресурсного підходу згідно запропонованої типології (див. табл. 1). Відтак, забезпечення ефективного функціонування та конкурентоспроможності логістичних систем як мікро-, так і мезота макрорівня (ЛЛТР) передбачає досягнення певного балансу між результативністю та ефективністю, консенсусу між якісними й кількісними показниками (див. рис. 1), оптимуму між рівнем логістичних витрат і якості обслуговування. Наведене твердження доводить доцільність використання комплексного підходу до діагностики ефективності ЛЛТР, який дозволить різнобічно оцінити функціонування матеріалопровідного ланцюга у внутрішньому та зовнішньому вимірі.

В теорії логістики немає єдиного універсального критерію до оцінки ефективності логістичних систем. Американські і європейські компанії для діагностики ефективності ЛД досить широко використовували модель М. Кристофера, що базується на трьох критеріях: якість обслуговування, час і витрати [4, c.144]. 3 огляду на іï недоліки (витрати дають лише часткову оцінку логістичної діяльності), цю модель було трансформовано в діаграму збалансованих переваг. Вона базується на ключових показниках ефективності логістичної системи, які визначаються безпосередньо стратегічними цілями суб'єктів ринку, з акцентом на «розриви» потокових процесів, що $\epsilon$ об'єктами управлінського впливу. Сьогодні іноземні компанії для діагностики ЛД застосовують модифікацію діаграми збалансованих переваг - діаграму (карmy) збалансованих показників, що базується на комплексному підході з акцентом на всебічну оцінку бізнес-процесів управління попитом та постачанням i технологій їх виконання та додаткову оцінку організаційних і технологічних аспектів ЛД [11, с. 37]. Однак карта збалансованих показників має два головні недоліки: (1) відсутність конкретизації показників; (2) недостатність інформації щодо логістичних витрат, як головного економічного показника. Над удосконаленням карти збалансованих показників нині плідно працюють іноземні та вітчизняні науковці.

Діагностичний напрям у дослідженні відтворювальних і потокових процесів товарних ринків $\epsilon$ відносно новим підходом, що виник на основі синтезу прикладних методів і процедур економічних, соціологічних, технічних і медицинських досліджень. Термін «діагностика» запозичений 3 медицини, він 
означає розпізнавання, визначення стану об'єкта. Економічна діагностика близька до аналізу, однак не тотожна йому, маючи інші завдання й інструментарій. Якщо аналіз акцентує увагу на встановленні відхилень кількісних значень індикаторів від цільових (або базових) величин, то діагностика визначає причини цих відхилень, досліджує причинно-наслідкові зв'язки між індикаторами. На думку О.Г. Дмитрієвої, діагностика - «це агрегований синтетичний висновок про стан досліджуваного об'єкта»; основна відмінність від аналізу полягає в їі цільовій орієнтованості на виявлення відхилень від норми, тобто «патології» [13].

У ринковому вимірі О.С. Новосьолов інтерпретує економічну діагностику як систему методів для аналізу чинників розвитку соціально-економічних процесів, оцінки стану і встановлення відхилень від нормального розвитку та їх впливу на формування й функціонування регіональних ринків $[15$, с.78]. Учений виділяє три напрями ринкової діагностики, у т.ч. діагностику розміщення виробництва й споживання, покликану визначити недоліки схем товароруху і визначити диспропорції в структурі виробництва й споживання [15, с.79]. Цей напрям діагностики має логістичний вимір та $є$ свідченням важливості здійснення діагностики товаропростування в ринку для його відтворювального розвитку. c.103]: (1) експрес-діагностика (оперативна);
Учені виділяють такі види діагностики [14, (2) функціональна (тематична); (3) комплексна; (4) системна. За формою оцінки результатів розрізняють кількісну діагностику (ії мета - вимірювання й порівняння різних показників, встановлення кількісної міри впливу різних чинників) та якісну (базується на якісних порівняльних оцінках, виявляє особливості стану об'єкта та його внутрішні взаємозалежності [13]. У даному дослідженні акцентуємо увагу на системній діагностиці, яка являє собою сукупність методів і прийомів дослідження певного об'єкту як багаторівневої системи та причинно-наслідкових зв'язків між іiі елементами. При цьому для інтерпретації отриманих результатів аналізу доцільно використовувати методи як кількісної, так і якісної діагностики.

На підставі проведеного дослідження теоретичних основ діагностики ефективності ЛЛТР сформулюємо авторське визначення дефініції (таблиця 2). Ефективність формування та функціонування ЛЛТР інтерпретуємо на основі комплексного підходу як систему збалансованих кількісно-якісних показників, яка різнобічно характеризує рівень якості функціонування матеріалопровідного ланцюга товарного ринку, співвідношення між досягнутим результатом і використаними ресурсами 3 цільовою орієнтацією на оптимізацію загальної ринкової доданої вартості.

Таблиця 2

Категорійна сукупність визначення сутності поняття «діагностика ефективності логістичних ланцюгів товарних ринків»"

\begin{tabular}{|c|c|}
\hline Категорія & Сутність (зміст) \\
\hline $\begin{array}{l}\text { Економічна } \\
\text { діагностика } \\
\text { (системна) }\end{array}$ & $\begin{array}{l}\text { 1. Система методів для аналізу чинників розвитку соціально-економічних процесів, оцінки } \\
\text { стану і встановлення відхилень від нормального розвитку та їх впливу на формування й } \\
\text { функціонування регіональних ринків [15, с.27] (мезорівень) } \\
\text { 2. Сукупність методів і засобів дослідження певного об’єкту як багатокомпонентної та ба- } \\
\text { гаторівневої системи; базується на комплексному підході, врахуванні причинно- } \\
\text { наслідкових зв’язків і взаємозалежностей між елементами системи [14, с.103] (мікрорі- } \\
\text { вень). }\end{array}$ \\
\hline $\begin{array}{l}\text { Ефективність } \\
\text { ЛЛТР } \\
\text { (комплексний } \\
\text { підхід) }\end{array}$ & $\begin{array}{l}\text { 1.Як економічна категорія ефективність дає єдину якісно-кількісну характеристику резуль- } \\
\text { тативності господарювання [17, с.508]. } \\
\text { 2. Система збалансованих кількісно-якісних показників, яка різнобічно характеризує рівень } \\
\text { якості функціонування матеріалопровідного ланцюга товарного ринку, співвідношення } \\
\text { між досягнутим результатом і використаними ресурсами з цільовою орієнтацією на опти- } \\
\text { мізацію загальної ринкової доданої вартості (aвт.) }\end{array}$ \\
\hline $\begin{array}{l}\text { Логістичний } \\
\text { ланцюг товар- } \\
\text { ного ринку }\end{array}$ & $\begin{array}{l}\text { Лінійно впорядкована (оптимізована) сукупність ланок з переміщення матеріальних і } \\
\text { пов’язаних з ними фінансових та інформаційних потоків на шляху від первинного джерела } \\
\text { сировини до кінцевого споживача готової продукції й переробки відходів, яка забезпечує } \\
\text { розширене відтворення товароруху в ринку (авт.) }\end{array}$ \\
\hline $\begin{array}{l}\text { Діагностика } \\
\text { ефективності } \\
\text { ЛЛТР }\end{array}$ & $\begin{array}{l}\text { Сукупність методів, прийомів та способів для аналізу за допомогою системи збалансова- } \\
\text { них кількісно-якісних показників стану потокових процесів товарного ринку, для оцінки } \\
\text { чинників впливу на розвиток матеріалопровідного ланцюга, причинно-наслідкових зв’язків } \\
\text { і міжланкових взаємодій, встановлення відхилень індикаторів від нормативних та оптима- } \\
\text { льних величин, розширеної інтерпретації причин логістичних «розривів» і визначення } \\
\text { шляхів їх подолання в товарному ринку (авт.) }\end{array}$ \\
\hline
\end{tabular}

"Розроблено автором на основі джерел $[14,15,17]$.

Авторське визначення категорії «діагностика ефективності ЛЛТР»є таким: сукупність методів, прийомів та способів для аналізу за допомогою системи збалансованих кількісно-якісних показників стану потокових процесів товарного ринку, для оцінки чинників впливу на розвиток матеріалопровідного ланцюга, причинно-наслідкових зв'язків і міжланкових взаємодій, встановлення відхилень індикаторів 
від нормативних та оптимальних величин, розширеної інтерпретації причин логістичних «розривів» i визначення шляхів їх подолання в товарному ринку. Запропоноване визначення акцентує увагу на комплексному підході до оцінки потокових процесів в ринкових ланцюгах, які є динамічною системою, ідентифікації на основі співставлень фактичних і еталонних індикаторів логістичних «розривів» у наскрізному матеріальному потоку та їх причин, що формує аналітичне підгрунтя для розробки механізмів та інструментів їх подолання для підвищення ефективності ЛЛТР.

Враховуючи результати проведених дослі- джень [19, 20, 21], структуру концептуального базису методології діагностики ефективності ЛЛТР доцільно представити як сукупність чотирьох наукових підходів, які, з одного боку, пов'язані між собою спільною відтворювальною основою, $з$ іншого, певним чином корелюють із відповідними групами принципів формування ефективних ринкових логістичних ланцюгів, а саме: відтворювальних, інтеграційних, регуляторних і принципів сталого розвитку (рис. 2). Концептуальний базис формує синтез відтворювального підходу, концепції діаграми збалансованих переваг, регуляторного підходу та концепції сталого розвитку. Розглянемо їх сутність та зв'язки більш детально.

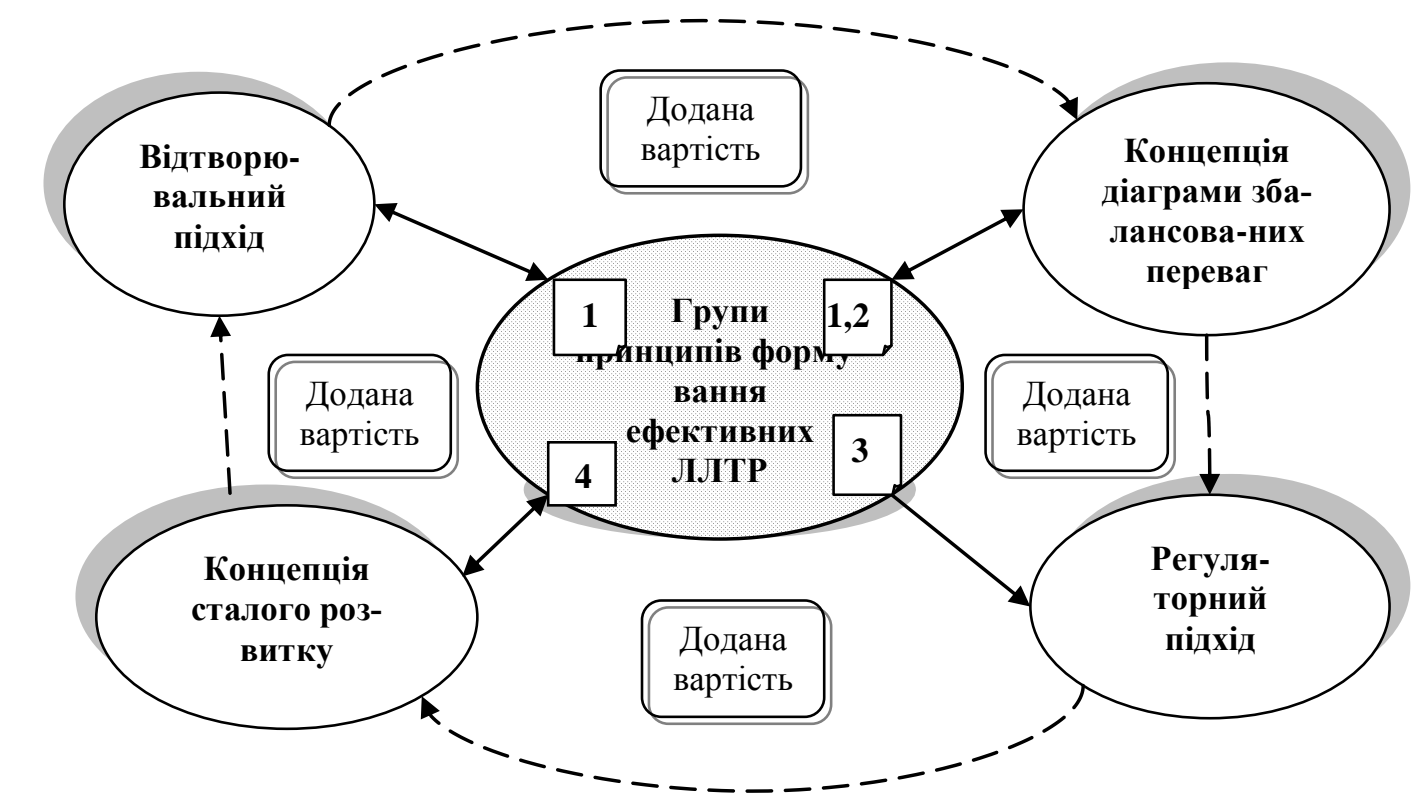

Групи принципів формування ефективних ЛЛТР: 1-відтворювальна; 2 - інтеграційна; $\mathbf{3}$ - регуляторна; $\mathbf{4}$ - принципи сталого розвитку.

\section{Рис. 2. Концептуальний базис методології діагностики ефективності логістичних ланцюгів товарних ринків * *авторська розробка}

Відтворювальний підхід є базовою методологічною платформою для розбудови ефективної логістики товарних ринків. Він передбачає забезпечення розширеного відтворення товароруху, тобто прискорення ринкового переміщення товару (від початкової до кінцевої ланки ЛЛТР) у зростаючих обсягах за рахунок узгодження параметрів наскрізного матеріального потоку між ланками ринкового логістичного ланцюга та нарощування його загальної доданої вартості. При цьому приріст ринкової доданої вартості може здійснюватися шляхом впровадження як логістичних, так і відтворювальних механізмів і заходів, зокрема, орієнтованих на спрямування сировинних потоків на внутрішню переробку, організацію ефективного товароруху вітчизняних продуктів переробки у внутрішньому й зовнішньому вимірі, інтеграцію українських ринків переробних товарів у глобальні ланцюги вартості.

Відтворювальний підхід базується на впровадженні відтворювальних принципів, до складу яких ми віднесли збалансованість матеріальних потоків (визначає пропорційність розширеного відтворення товароруху в ринковому ланцюгу), оптимізацію наскрізних матеріальних потоків (характеризує результативність трансформації будови ЛЛТР), повернення фінансових потоків (інвестиційне забезпечення розширеного відтворення товароруху в ринку). Емпіричні дослідження засвідчили порушення відтворювальних принципів формування ланцюгів стратегічних товарних ринків в Україні $[19,21]$.

Кониепція діаграми збалансованих переваг базується на сукупності ключових показників ефективності логістичної системи, безпосередньо пов'язаних зі стратегічними цілями та логістичними стратегіями ії суб'єктів. На наш погляд, дана концепція може бути використана в ході діагностики ефективності не тільки мікро-, а й макрологістичних систем, зокрема ЛЛТР. Головною стратегічною метою функціонування ринкового логістичного ланцюга $\epsilon$ розширене відтворення товароруху в ринку, головним критерієм оцінки його ефективності - оптимізація загальної ринкової доданої вартості. 3 огляду на відсутність конкретизації показників, практичне впровадження діаграми збалансованих переваг на макрорів- 
ні передбачає конструювання системи взаємопов'язаних індикаторів, що характеризують процес формування та перерозподілу доданої вартості за ланками ЛЛТР, динаміку їі змін в часовому вимірі, відхилення від цільових параметрів тощо. Така система діагностичних показників, 3 одного боку, повинна відображати ступінь реалізації стратегічної інтегрованої мети ЛЛТР, з іншого, бути збалансованою за якісно-кількісними компонентами відповідно до вимог комплексного підходу до діагностування логістичних систем.

На практиці іноземні компанії для діагностики ЛД застосовують модифікацію діаграми збалансованих переваг - систему збалансованих показників (balanced scorecard - BSC). Цілі і показники BSC формуються в залежності від стратегії кожного підприємства і характеризують його діяльність за чотирма напрямами: (1) фінанси; (2) взаємовідносини 3 покупцями; (3) внутрішні бізнес-процеси; (4) навчання і розвиток персоналу. Ці складові системи включають від 3 до 7 різних параметрів і індикаторів, тому BSC підприємства складається в середньому з 25-ти показників [22]. Необхідно відзначити, що фінансова складова BSC, окрім рентабельності інвестицій, містить додану вартість, забезпечуючи зв'язок оціночної системи із відтворювальним підходом до діагностики ефективності логістичних систем.

Підсумовуючи викладене, слід підкреслити зв'язок концепції діаграми збалансованих переваг із відтворювальним підходом через стратегічну мету та цільовий орієнтир ЛЛТР та регуляторним підходом в аспекті визначення базових ланок ринкового ланцюга, які шляхом впровадження регуляторних заходів держави мають перспективу перетворення в драйвери ефективності логістичних ланцюгів стратегічних товарних ринків країни (див. рис. 2).

Впровадження концепції діаграми збалансованих переваг у макрологістичних системах базується на відтворювальних та інтеграційних принципах розбудови ефективних ЛЛТР. До складу останніх ми віднесли паритетність інтеграційних взаємодій між суб'єктами різних ланок ланцюга на засадах узгодження їх економічних інтересів та оптимізацію інтеграційних зв'язків між ними [19]. Інтеграційні принципи мають важливе значення для подолання конфліктів локальних і загальних цілей ЛЛТР, формування єдиної стратегічної мети та спільного критерію оптимізації потокових процесів у ринку, оптимізації управління не дискретним, а наскрізним матеріальним потоком.

Регуляторний підхід (див. рис. 2) передбачає участь держави в управлінні потоковими процесами в стратегічних товарних ринках шляхом стимулювання розвитку (створення) базових ланок, як драйверів ефективності ЛЛТР, або нівелювання (зменшення) логістичних «розривів», що генерують зменшення або відтік доданої вартості із матеріалопровідного ланцюга, знижуючи його ефективність. Механізми та інструменти державного селективного впливу на базові ланки ринкових ланцюгів або логістичні «розриви» повинні відповідати діючій концепції державної політики та стратегічним орієнтирам національної економічної безпеки.

Для оцінки ефективності регуляторних заходів держави доцільно використати систему показни- ків у складі відтворювального, податкового та соціального ефектів, що розраховуються на базі критерію доданої вартості. Мірилом ефективності регуляторних заходів є приріст загальної доданої вартості в ЛЛТР після їх впровадження. Із іншими концепціями регуляторний підхід пов'язаний цільовим орієнтиром державного впливу у формі відтворювального ефекту. Даний підхід базується на чотирьох регуляторних принципах формування ЛЛТР, а саме: (1) пріоритетність економічних інтересів держави; (2) цілеспрямованість; (3) ефективність; (4) зворотного зв'язку [19]. Змістом першого принципу є розбудова та трансформація логістичних ланцюгів стратегічних товарних ринків не $з$ позиції економічних інтересів окремих суб'єктів ринку або ланок, а держави як носія суспільних інтересів. Це має принципове значення в ході інтерпретації діагностичних показників, оскільки підвищення ефективності всієї логістичної системи може досягатись за рахунок зменшення доходності певних їі ланок (наприклад, посередницької).

Сучасний вектор державної політики характеризується активізацією програм впровадження Цілей сталого розвитку до 2030 р., проголошених резолюцією Генеральної Асамблеї ООН № 70/1 від 25.09.2015 р. [23]. Процес інституціоналізації компонентів збалансованого розвитку, що розпочався в Україні, обумовлює необхідність інтеграції показників сталого розвитку у систему індикаторів для діагностики ефективності ЛЛТР. 3 іншого боку, ефективна ринкова матеріалопровідна система повинна бути екологічною й ресурсозаощадливою, базуватись на принципах сталого розвитку, до складу яких нами віднесено мінімізацію втрат ресурсів, замкненість циклів та ринкову інклюзію $[19,21]$.

Підсумовуючи викладене, слід відзначити, що цільовий орієнтир ринкової логістики - розширене відтворення товароруху та оптимізація загальної доданої вартості в ЛЛТР - притаманний усім науковим підходам (див. рис. 2). Синтез чотирьох підходів у методології діагностики ефективності ЛЛТР дозволяє максимально повно охопити різноаспектні параметри розбудови та функціонування ринкової логістичної системи, що формує наукове підгрунтя для розробки системи збалансованих оціночних показників.

Теоретико-методологічне забезпечення діагностики ефективності логістичних ланцюгів товарних риків, що пропонується автором, поєднує концептуальний і методичний базиси, складові яких наведено на рис. 3. Головною метою діагностики є багаторівнева оцінка ефективності формування та функціонування ЛЛТР за допомогою системи збалансованих кількісно-якісних показників стану потокових процесів товарного ринку та встановлення логістичних «розривів» цих процесів, проблемних місць у ринковому товарорусі, як методичний базис прийняття конструктивних управлінських рішень для забезпечення розширеного товароруху в ринку та обгрунтування регуляторних механізмів.

Серед наведених 9-ти завдань діагностики центральне місце належить встановленню причиннонаслідкових зв'язків між оціночними показниками, відхилень фактичних їх значень від нормативних або оптимальних рівнів, визначення системних і локаль- 
них логістичних «розривів» потокових процесів i причин їх виникнення в товарному ринку, агрегований висновок про поточний стан функціонування ринкового ланцюга та обгрунтування шляхів і заходів досягнення його цільових орієнтирів. Враховуючи важливість ефективної інтеграції вітчизняних товарних ринків до глобальних ланцюгів вартості, до складу діагностичних завдань віднесено оцінку трансформаційного впливу глобалізаційних чинників на стан українських ЛЛТР (див. рис. 3).

\begin{tabular}{|c|c|}
\hline & 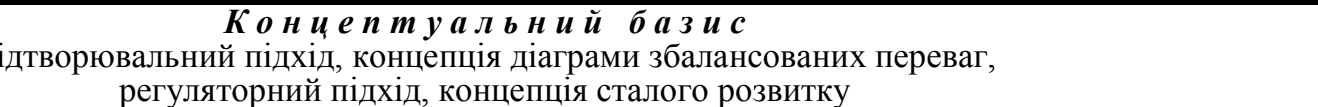 \\
\hline $\begin{array}{l}\text { Багаторівнева оцінка } \\
\text { них кількісно-якісних } \\
\text { зривів»цих процесів, } \\
\text { ких рішень для забезп } \\
\text { вартістю в ланцюгах с }\end{array}$ & $\begin{array}{l}\text { Мета діагностики ефективності функціонування ЛЛТP: } \\
\text { фективності формування та функціонування ЛЛТР за допомогою системи збалансова- } \\
\text { Іоказників стану потокових процесів товарного ринку та встановлення логістичних «ро- } \\
\text { троблемних місць у ринковому товарорусі, як методичний базис прийняття управлінсь- } \\
\text { чення розширеного товароруху в ринку, обгрунтування механізмів управління доданою } \\
\text { ратегічних товарних ринках країни }\end{array}$ \\
\hline $\begin{array}{l}\text { 1. Систематизація інфс } \\
\text { 2. Оцінка стану форму } \\
\text { основі комплексного п } \\
\text { 3. Визначення відхиле } \\
\text { 4. Встановлення базов } \\
\text { вплив на функціонуваг } \\
\text { 5. Дослідження причи } \\
\text { 3в’язків між оціночнил } \\
\text { 6. Оцінка трансформац } \\
\text { 7. Розширена інтерпре } \\
\text { 8. Агрегований виснов } \\
\text { 9. Обгрунтування шля) } \\
\text { (зменшення) їх логісти }\end{array}$ & $\begin{array}{l}\text { aвдання діагностики ефективності функціонування ЛЛТР: } \\
\text { рмаційних потоків у розрізі головних напрямів системної діагностики } \\
\text { вання та функціонування ЛЛТР, логістичних тенденцій розвитку товарного ринку на } \\
\text { дходу. } \\
\text { Іы фактичних показників від нормального або оптимального стану ЛЛТР. } \\
\text { их логістичних «розривів» потокових процесів, які здійснюють системний глибинний } \\
\text { ня ринкового ланцюга. } \\
\text { в встановлених відхилень і логістичних «розривів», виявлення причинно-наслідкових } \\
\text { и показниками. } \\
\text { ійного впливу глобалізаційних чинників на стан вітчизняних ЛЛТР. } \\
\text { ація показників, індикаторів, логістичних процесів і тенденцій релевантного ринку. } \\
\text { ок про стан функціонування ЛЛТР та оцінка перспектив його розвитку. } \\
\text { ів, механізмів і заходів оптимізації потокових процесів товарного ринку та нівелювання } \\
\text { чних «розривів» }\end{array}$ \\
\hline & Принципи діагностики ефективності ЛЛТР: \\
\hline $\begin{array}{l}\text { 1. Системність i } \\
\text { комплексність }\end{array}$ & $\begin{array}{l}\text { Оцінка ефективності ЛЛТР як складної динамічної системи проводиться з урахуван- } \\
\text { ням всіх внутрішніх і зовнішніх зв’язків між ланками і суб'єктами, забезпечуючи все- } \\
\text { бічне дослідження причинно-наслідкових залежностей у логістичнй системі }\end{array}$ \\
\hline $\begin{array}{l}\text { 2.Адекватність } i \\
\text { динамічність }\end{array}$ & $\begin{array}{l}\text { Відповідність способів і прийомів діагностики сучасним закономірностям плинності } \\
\text { ринкових процесів відтворення, діагностика потокових процесів товарного ринку у } \\
\text { постійному розвитку }\end{array}$ \\
\hline $\begin{array}{l}\text { 3.Об'єктивність } i \\
\text { точність }\end{array}$ & $\begin{array}{l}\text { Інформаційна база для діагностики повинна бути достовірною, а ії результати обгрун- } \\
\text { товуватися точними аналітичними розрахунками }\end{array}$ \\
\hline 4. Дієвість & $\begin{array}{l}\text { Результати діагностики ефективності ЛЛТР повинні мати прикладне значення, слугу- } \\
\text { вати базою для прийнятяя заходів щодо нівелювання (зменшення) логістичних «розри- } \\
\text { вів» та оптимізації потокових процесів товарного ринку. }\end{array}$ \\
\hline 5. Цілеспрямованість & $\begin{array}{l}\text { Орієнтованість на досягнення стратегічної мети ЛЛТР - розширене відтворення това- } \\
\text { роруху в ринку, оптимізацію загальної ринкової доданої вартості. }\end{array}$ \\
\hline 6. Науковість & $\begin{array}{l}\text { Постійне удосконалення методик діагностики та використання передового світового } \\
\text { досвіду щодо діагностики ефективності розбудови та функціонування ЛЛТР }\end{array}$ \\
\hline & Методичнй баз бис \\
\hline $\begin{array}{l}\text { Методичні положег } \\
\text { 1. Ідентифікація релеє } \\
\text { вні суб’єкти ринку } \\
\text { 2. Діагностика ефект } \\
\text { 2.1. Діагностика ефе } \\
\text { 2.2. Діагностика ефе } \\
\text { 2.3. Діагностика пот } \\
\text { 2.4. Діагностика тенғ } \\
\text { 2.5. Діагностика яко } \\
\text { 3. Агрегований виснов } \\
\text { між ключовими показю }\end{array}$ & $\begin{array}{l}\text { ня діагностики ефективності функціонування ЛЛТР. Головні етапи діагностики: } \\
\text { антного ринку: товарні, територіальні та часові межі ринку, ємність, структура та голо- } \\
\text { вності ЛЛТР за допомогою системи збалансованих кількісно-якісних показників: } \\
\text { стивності формування, перерозподілу та структури доданої вартості в ЛЛТР. } \\
\text { тивності ресурсовикористання та часових параметрів ЛЛТР. } \\
\text { жності руху внутрішніх і зовнішніх матеріальних потоків у ЛЛТР. } \\
\text { енцій сталого розвитку ЛЛТР. } \\
\text { ті логістичного обслуговування в товарному ринку. } \\
\text { ок про стан і проблеми ринкової логістики, встановлення причинно-наслідкових зв'язків } \\
\text { иками, оцінка міжланкових балансів показників ефективності ЛЛТР. }\end{array}$ \\
\hline cmpamea & $\begin{array}{l}\text { Пріоритети національної політики в ринковому вимірі, } \\
\text { iі оріснтири логістичного розвитку товарних ринків в умовах глобалізачї }\end{array}$ \\
\hline $\begin{array}{l}\text { 1. Інституційні } \\
\text { 2. Фінансово-економіч }\end{array}$ & $\begin{array}{c}\text { Механізми державного регулювання: } \\
\text { 3. Адміністративні } \\
\text { 4. Інформаційні }\end{array}$ \\
\hline $\begin{array}{l}\text { Методичні положення } \\
\text { механізмів і заходів } \\
\text { регулювання. }\end{array}$ & $\begin{array}{l}\text { діагностики ефективності регулювання базових ланок ЛЛТР: ефекти від впровадя } \\
\text { егулювання (відтворювальний, логістичний, податковий, соціальний); рентабель }\end{array}$ \\
\hline
\end{tabular}

Рис. 3. Структурна схема теоретико-методологічного забезпечення діагностики ефективності логістичних ланцюгів товарного ринку*

*авторська розробка 
Невід'ємною складовою методологічного забезпечення є приниципи діагностики ефективності функціонування логістичних ланцюгів товарних ринків, до складу яких автором віднесено наступні (див. рис. 3): (1) системність і комплексність; (2) адекватність і динамічність; (3) об'єктивність і точність; (4) дієвість; $\quad$ (5) цілеспрямованість; (6) науковість. Виділені принципи орієнтують вектор дослідження на об'єктивну діагностику ефективності функціонування як ланок, так ринкового ланцюга в цілому з позиції економічних інтересів держави, а не окремих суб'єктів, на цільове досягнення стратегічної мети інтегрованого ЛЛТР та встановлення логістичних «розривів» потокових процесів, на практичній значимості методичних положень, як аналітичної бази для прийняття конструктивних управлінських рішень щодо нівелювання (зменшення) таких «розривів» та оптимізації загальної ринкової доданої вартосTi.

Методичний базис включає методичні положення діагностики ефективності формування та функціонування ЛЛТР, агрегований висновок про стан і ключові проблеми матеріалопровідної системи певного товарного ринку, оцінку міжланкових балансів іiі показників ефективності, як основу для прийняття управлінських рішень щодо механізмів і заходів управлінського впливу, узгоджених із пріоритетами державної політики й стратегічними напрямами логістичного розвитку релевантного ринку, а також методичні положення оцінки ефективності регулювання ЛЛТР (див. рис. 3). Таким чином, методичні положення діагностики ефективності ЛЛТР органічно вбудовані в загальний методологічний фундамент ринкового дослідження і тісно взаємопов'язані з процесами моніторингу, оцінки, прогнозування та управління товарними ринками.

Висновки та перспективи подальших досліджень. У ході дослідження виділено три підходи до трактування категорії «ефективність логістичної системи», а саме: (1) якісний (цільовий і споживчоорієнтований); (2) кількісний (ресурсний і результуючий); (3) комплексний (синтезуючий якісний i кількісний підходи). Обгрунтовано доцільність використання комплексного підходу до теоретичного осмислення та діагностики потокових процесів товарних ринків, який забезпечує збалансованість (консенсус) якісних і кількісних показників, органічне поєднання діагнос- тики внутрішнього й зовнішнього середовища логістичних систем, що є важливою умовою забезпечення конкурентоспроможності ринкових ланцюгів. На основі проведеного дослідження концептуальної сутності компонентів категорії «діагностика ефективності ЛЛТР» запропонованої іiі авторське визначення: сукупність методів, прийомів та способів для аналізу за допомогою системи збалансованих кількісно-якісних показників стану потокових процесів товарного ринку, для оцінки причинно-наслідкових зв'язків і міжланкових взаємодій, розширеної інтерпретації причин логістичних «розривів» і визначення шляхів їх подолання в товарному ринку.

Обгрунтовано концептуальний базис шляхом синтезу трьох наукових підходів (відтворювального, регуляторного, концепцій діаграми збалансованих переваг і сталого розвитку), що взаємопов'язані між собою спільною відтворювальною основою та корелюють із відповідними групами принципів формування ефективних ланцюгів товарних ринків. Розроблено теоретико-методологічне забезпечення діагностики ефективності ЛЛТР, що поєднало концептуальний базис як сукупність цілей, завдань і принципів діагностики, та методичний базис як сукупність методичних положень діагностики ефективності функціонування ринкових ланцюгів, механізмів державного регулювання та методичних положень щодо оцінки ефективності їх впровадження в базових ланках ланцюгів товарних ринків.

Наукова новизна проведеного дослідження полягає в удосконаленні теоретико-методологічних засад ринкової логістики в частині визначення сутності категорій «ефективність» і «діагностика» в ринково-логістичному вимірі, обгрунтуванні складових концептуального базису, методологічних принципів та методичних положень діагностики ефективності функціонування ЛЛТР. Практичне значення результатів дослідження визначається можливістю їх використання органами влади різних рівнів як науковометодичне підгрунтя для встановлення системних «розривів» потокових процесів товарних ринків та розробки регуляторних механізмів і заходів їх подолання. Перспективи подальших досліджень полягають у конструюванні системи збалансованих кількісно-якісних показників для діагностики ефективності функціонування й трансформації будови логістичних ланцюгів товарних ринків.

\section{Література}

1. Witkowski J. Metodologiczne podstawy strategii logistycznej w rzedsiębiorstwie // GmiL. 1993. № 12. P. 214-217.

2. Гудков В.А., Миротин Л.Б., Ширяев С.А. и др. Основы логистики / Под ред. В.А. Гудкова. М.: Горячая линия-Телеком, 2004. $351 \mathrm{c}$.

3. Гурч Л.М. Логістика: навч. посібник. К.: ДП «Видавчничий дім «Персонал», 2008. 560 с.

4. Кристофер М. Логистика и управление цепочками поставок / Кристофер М.: пер. с англ.; под общ. ред. В.С. Лукинского. СПб.: Питер, 2004. 316 с.

5. Миротин Л.Б., Ташбаев Ы.Э. Логистика для предпринимателя: основные понятия, положения, процедуры. М.: ИНФРА-М, 2003. 252 с. 
6. Осипенко С.М. Управління ефективністю логістичної діяльності підприємства на основі факторноопераційного підходу // Логистика: проблемы и решения. 2013. №1 (44). С.85-89. 2005. $328 \mathrm{c}$.

7. Пономарьова Ю. В. Логістика: навч. посібник.. 2-ге вид, перероб. та доп. К.: Центр навч. літ-ри

8. Руденко Г.Р. Оцінка ефективності логістичної діяльності на машинобудівних підприємствах на засаді таксономічного аналізу: інноваційний підхід // Проблеми науки. 2009. №9. С.40-43.

9. Сагайдак-Никитюк Р.В. Методика оценки эффективности логистической деятельности фармацевтического предприятия // Логистика: проблемы и решения. 2011. №6 (37). С.32-39.

10. Семененко А.И., Сергеев В.И. Логистика. Основы теории. СПб: Союз, 2003. 544 с.

11. Сумець О.М. Сучасні підходи до визначення ефективності логістичної діяльності підприємства та ії оцінювання //Логистика: проблемы и решения. 2019. №6 (85). С.32-42.

12. Талан М.В. Моделювання логістичних стратегій торговельних підприємств // Вісник Інституту підприємництва та перспективних технологій при Національному університеті «Львівська політехніка». 2008. №633. С.696-701.

13. Дмитриева О.Г. Региональная экономическая диагностика. СПб.: Изд-во Санкт-Петербургского унта экономики ифинансов, 1992. $274 \mathrm{c}$.

14. Ковалев А.И. Управление реструктуризацией предприятия: монография. Киев: АВРИО, 2006. 368 с.

15. Новоселов А.С. Теория региональных рынков. Новосибирск: Сибирское соглашение, 2002. 448 с.

16. Момот О. І., Демченко А.О. Про сутність понять «ефективність» та «результативність» в економіці // Економічний вісник Донбасу. 2013. №3 (33). С. 207-210.

17. Економічна енциклопедія: в 3т. Т.1. / відп. ред. Мочерний С. В. та ін. К.: Вид. центр «Академія», 2002. $864 \mathrm{c}$.

18. Shteberg D. Supply Chain Efficiency vs. Effectiveness. URL: https://www.handshake.com/blog/supplychain-efficiency-vs-effectiveness (дата звернення 04.04.2020).

19. Буркинський Б.В., Нікішина О.В. Принципи формування ефективних логістичних ланцюгів товарних ринків: монограф. Одеса: ІПРЕЕД НАН України, 2019. 80 с.

20. Буркинський Б.В., Нікішина О.В., Лисюк В.М. та ін. Методологічні засади формування ефективної логістики товарних ринків: монографія / за ред. Б.В. Буркинського, О.В. Нікішиної. Одеса: ІПРЕЕД НАН України, 2020. 200 с.

21. Нікішина О.В. Інклюзивний підхід до формування логістичних ланцюгів аграрного ринку України // Економіка АПК. 2020. №1. С.46-55. doi: 10.32317/2221-1055.202001046

22. Balanced Scorecard (BSC) URL: https://studme.com.ua/125906058799/informatika/sistema_sbalansirovannyh_pokazateley_bsc_effektivnosti.htm\#77 (дата звернення 04.04.2020).

23. Цілі Сталого розвитку 2016-2030. URL: http://www.un.org.ua/ua/tsili-rozvytku-tysiacholittia/tsilistaloho-rozvytku (дата звернення 04.04.2020).

Стаття надійшла 10.04.2020

Стаття прийнята до друку 24.04.2020

Доступно в мережі Internet 11.07.2020

Никишина О.В.

доктор экономических наук, старший научный сотрудник, заведующий отделом рыночных механизмов и структур

Институт проблем рынка и экономико-

экологических исследований НАН Украины

Французский бульвар, 29, г. Одесса, Украина, 65044

E-mail: ksenkych@gmail.com.

ORCID ID: 0000-0002-7172-3551

\section{ТЕОРЕТИКО-МЕТОДОЛОГИЧЕСКОЕ ОБЕСПЕЧЕНИЕ ДИАГНОСТИКИ ЭФФЕКТИВНОСТИ ЛОГИСТИЧЕСКИХ ЦЕПЕЙ TOВАРНЫХ РЫНКОВ}

Статья посвящена обоснованию теоретических и методологических основ системной диагностики эффективности функционирования логистических цепей товарных рынков. На основании теоретического обобщения выделено три подхода к определению сущности категории «эффективность логистической системы», а именно: (1) качественный (целевой и ориентированный на потребителя); (2) количественный (ресурсный и результирующий); (3) комплексный. Доказана целесообразность ис- 
спользования комплексного подхода для диагностики эффективности рыночных цепей, обеспечивающего сбалансированность качественных и количественных показателей, сочетание оценок внутренней и внешней среды логистических систем. По результатам анализа категорий «эффрективность» и «диагностика» в рыночно-логистическом измерении дано авторское определение категории «диагностика эфффективности логистических цепей товарных рынков».

Обоснованы составляющие концептуального базиса на основе синтеза четырех подходов (воспроизводственного, регуляторного, концепций диаграммы сбалансированных преимуществ и устойчивого развития), доказана их взаимосвязь между собой общей воспроизводственной основой и их корреляция с соответствующими группами принципов формирования эффективных цепей товарных рынков. Разработано теоретико-методологическое обеспечение диагностики эффективности логистических цепей товарных рынков, объединившее концептуальный базис, как совокупность целей, задач и принципов диагностики, и методический базис. Он включил совокупность методических положений диагностики эффективности функционирования рыночных цепей, механизмов государственного регулирования и методических положений по оценке эффективности их внедрения в базовых звеньях цепей товарных рынков.

Научная новизна исследования состоит в усовершенствовании теоретико-методологических основ рыночной логистики в части определения сущности категорий «эффективность» и «диагностика» В рыночно-логистическом измерении, обосновании составляющих концептуального базиса, методологических принципов и методических положений диагностики эффективности функционирования логистических цепей товарных рынков. Практическое значение результатов исследования определяется возможностью их использования органами власти, как научно-методической основы для разработки механизмов регулирования базовых звеньев рыночных цепей.

Ключевые слова: эффективность, диагностика, подход, логистическая цепь товарного рынка, принципы диагностики, добавленная стоимость, система показателей.

\section{Nikishyna 0.}

Doctor of Economics, Senior Researcher

Head of Department of Market Mechanisms and Structures

Institute of Market Problems and Economic \& Ecological Research

of National Academy of Sciences of Ukraine

Frantsuzskiy boulevard, 29, Odesa, Ukraine, 65044

E-mail: ksenkych@gmail.com

ORCID ID: 0000-0002-7172-3551

\section{THEORETICAL AND METHODOLOGICAL SUPPORT OF DIAGNOSTICS OF EFFICIENCY OF LOGISTIC CHAINS OF COMMODITY MARKETS}

The article is devoted to substantiation of theoretical and methodological foundations of system diagnostics efficiency of functioning of logistic chains of commodity markets. On the basis of theoretical generalization, three approaches to determining the essence of the category «efficiency of the logistics system» have been distinguished, namely: (1) qualitative (targeted and consumer oriented); (2) quantitative (resource and resultant); (3) complex. The expediency of using a comprehensive approach to diagnose the effectiveness of market chains, which provides a balance of qualitative and quantitative indicators, a combination of assessments of the internal and external environment of logistics systems has been proved. According to the results of the analysis of the categories «efficiency» and «diagnostics» in the market-logistic dimension, the author's definition of the category «diagnostics of the efficiency of logistics chains of commodity markets» has been given.

The components of the conceptual basis have been grounded on the basis of synthesis of four approaches (reproductive, regulatory, concepts of the balance of benefits and sustainable development), their interrelation within the common reproductive basis and their correlation with the corresponding groups of principles of formation of effective chains of commodity markets have been proved. Theoretical and methodological providing of diagnostics of efficiency of logistic chains of commodity markets has been developed, which combined conceptual basis, as a set of goals, tasks and principles of diagnostics, and methodical basis. He included a set of methodological provisions for diagnostics of the efficiency of functioning of market chains, mechanisms of state regulation and methodical provisions for evaluating the effectiveness of their implementation in the basic links of chains of commodity markets. 
The scientific novelty of the research is to improve the theoretical and methodological foundations of market logistics in terms of defining the essence of the categories «efficiency» and «diagnostics» in the marketlogistic dimension, substantiation of the components of the conceptual basis, methodological principles and methodological provisions of diagnostics efficiency of functioning of logistic chains of commodity markets. The practical importance of the results of the study is determined by the possibility of their use by the authorities as a scientific and methodological basis for the development of mechanisms for regulating the basic links of market chains.

Key words: efficiency, diagnostics, approach, logistic chain of commodity market, principles of diagnostics, added value, system of indicators.

\section{References}

217.

1. Witkowski, J. (1993). Metodologiczne podstawy strategii logistycznej w rzedsiębiorstwie. GmiL, (12), 214-

2. Gudkov, V. A., Mirotin, L. B., \& Shiryaev, S. A. (2004). Osnovyi logistiki. V. A. Gudkov (Ed.). Moscow: Goryachaya liniya-Telekom.

3. Hurch, L. M. (2008). Lohistyka. Kyiv: DP «Vydavchnychyi dim «Personal».

4. Kristofer, M. (2004). Logistika i upravlenie tsepochkami postavok. (M. Kristofer, Trans.). V. S. Lukinskiy (Ed.). SPb.: Piter.

5. Mirotin, L. B., \& Tashbaev, Yi. E. Logistika dlya predprinimatelya: osnovnyie ponyatiya, polozheniya, protseduryi. Moscow: INFRA-M.

6. Osypenko, S. M. (2013). Upravlinnia efektyvnistiu lohistychnoi diialnosti pidpryiemstva na osnovi faktorno-operatsiinoho pidkhodu. Logistika: problemyi i resheniya, (1 (44)), 85-89.

7. Ponomarova, Yu. V. (2005). Lohistyka. (2nd ed.). Kyiv: Tsentr navch. lit-ry.

8. Rudenko, H. R. (2009). Otsinka efektyvnosti lohistychnoi diialnosti na mashynobudivnykh pidpryiemstvakh na zasadi taksonomichnoho analizu: innovatsiinyi pidkhid. Problemy nauky, (9), 40-43.

9. Sagaydak-Nikityuk, R. V. (2011). Metodika otsenki effektivnosti logisticheskoy deyatelnosti farmatsevticheskogo predpriyatiya. Logistika: problemyi i resheniya, (6 (37)), 32-39.

10. Semenenko, A. I., \& Sergeev, V. I. (2003). Logistika. Osnovyi teorii. SPb: Soyuz.

11. Sumets, O. M. (2019). Suchasni pidkhody do vyznachennia efektyvnosti lohistychnoi diialnosti pidpryiemstva ta yii otsiniuvannia. Logistika: problemyi i resheniya, (6 (85)), 32-42.

12. Talan, M. V. (2008). Modeliuvannia lohistychnykh stratehii torhovelnykh pidpryiemstv. Visnyk Instytutu pidpryiemnytstva ta perspektyvnykh tekhnolohii pry Natsionalnomu universyteti «Lvivska politekhnika», (633), 696-701.

13. Dmitrieva, O. G. (1992). Regionalnaya ekonomicheskaya diagnostika. SPb.: Izd-vo Sankt-Peterburgskogo un-ta ekonomiki ifinansov.

14. Kovalev, A. I. (2006). Upravlenie restrukturizatsiey predpriyatiya. Kiev: AVRIO.

15. Novoselov, A. S. (2002). Teoriya regionalnyih ryinkov. Novosibirsk: Sibirskoe soglashenie.

16. Momot, O. I., \& Demchenko, A. O. (2013). Pro sutnist poniat «efektyvnist» ta «rezultatyvnist» V ekonomitsi. Ekonomichnyi visnyk Donbasu, (3 (33)), 207-210.

17. Mochernyi, S. V. (Ed.). (2002). Ekonomichna entsyklopediia. 1. Kyiv: Vyd. tsentr «Akademiia».

18. Morse, A. (2018, April 12). Supply Chain Efficiency vs. Effectiveness. Handshake. Retrieved April 4, 2020, from https://site.handshake.com/blog/supply-chain-efficiency-vs-effectiveness

19. Burkynskyi, B. V., \& Nikishyna, O.V. (2019). Pryntsypy formuvannia efektyvnykh lohistychnykh lantsiuhiv tovarnykh rynkiv. Odesa: IPREED NAN Ukrainy.

20. Burkynskyi, B. V., Nikishyna, O. V., \& Lysiuk, V. M. (2020). Metodolohichni zasady formuvannia efektyvnoi lohistyky tovarnykh rynkiv. B. V. Burkynskyi, \& O.V. Nikishyna (Eds). Odesa: IPREED NAN Ukrainy.

21. Nikishyna, O. V. (2020). Inkliuzyvnyi pidkhid do formuvannia lohistychnykh lantsiuhiv ahrarnoho rynku Ukrainy. Ekonomika APK, (1), 46-55. doi: 10.32317/2221-1055.202001046
22. Balanced
Scorecard
(BSC).
Studme.com.ua.
Retrieved April 4, 2020, from https://studme.com.ua/125906058799/informatika/sistema_sbalansirovannyh_pokazateley_bsc_effektivnosti.htm\# 77

23. Tsili Staloho rozvytku 2016-2030. United Nations Ukraine. Retrieved April 4, 2020, from http://www.un.org.ua/ua/tsili-rozvytku-tysiacholittia/tsili-staloho-rozvytku

Received 10 April 2020

Approved 24 April 2020

Цитування згідно ДСТУ 8302:2015

Available in Internet 11.07.2020

Нікішина О.В. Теоретико-методологічне забезпечення діагностики ефективності логістичних ланцюгів товарних ринків // Економіка харчової промисловості. 2020. Т.12, вип. 2. С. 3-14. doi: 10.15673/fie.v12i2.1734

Cite as APA style citation

Nikishyna, O. (2020). Theoretical and methodological support of diagnostics of efficiency of logistic chains of commodity markets. Food Industry Economics, 12(2), 3-14. doi: 10.15673/fie.v12i2.1734 